University of Wollongong

Research Online

Faculty of Engineering - Papers (Archive)

Faculty of Engineering and Information

Sciences

1999

\title{
Nickel Hydroxide as an Active Material for the Positive Electrode in Rechargeable Alkaline Batteries
}

J Chen

University of Wollongong

D. H. Bradhurst

University of Wollongong

SX. Dou

University of Wollongong, shi@uow.edu.au

Hua-Kun Liu

University of Wollongong, hua@uow.edu.au

Follow this and additional works at: https://ro.uow.edu.au/engpapers

Part of the Engineering Commons

https://ro.uow.edu.au/engpapers/119

\section{Recommended Citation}

Chen, J; Bradhurst, D. H.; Dou, S X.; and Liu, Hua-Kun: Nickel Hydroxide as an Active Material for the Positive Electrode in Rechargeable Alkaline Batteries 1999.

https://ro.uow.edu.au/engpapers/119

Research Online is the open access institutional repository for the University of Wollongong. For further information contact the UOW Library: research-pubs@uow.edu.au 


\title{
Nickel Hydroxide as an Active Material for the Positive Electrode in Rechargeable Alkaline Batteries
}

\author{
J. Chen,* D. H. Bradhurst, S. X. Dou, and H. K. Liu**,z
}

Institute for Superconducting and Electronic Materials, University of Wollongong, New South Wales 2522, Australia

\begin{abstract}
Spherical nickel hydroxide powders coprecipitated with the additives $\mathrm{Ca}(\mathrm{OH})_{2}, \mathrm{Co}(\mathrm{OH})_{2}$, and $\mathrm{Zn}(\mathrm{OH})_{2}$ were prepared through a spraying technique. These powders, which have a higher tapping density and a much smaller pore volume and crystalline size than conventional powders, were used as the active materials of nickel hydroxide electrodes. The effects of the $\mathrm{Ca}(\mathrm{OH})_{2}, \mathrm{Co}(\mathrm{OH})_{2}$, and $\mathrm{Zn}(\mathrm{OH})_{2}$ additions on electrode properties such as charge-discharge, reversibility of the electrode reaction, and cycle life, were studied. The relationship between the electrode swelling and the formation of $\gamma-\mathrm{NiOOH}$ was also investigated. The results show that nickel hydroxide powders having a smaller crystallite size show better electrode characteristics such as lower overpotential, higher plateau discharge potential, and higher capacity. The utilization of the active material in the electrodes illustrates that for general use it is better to add $\mathrm{Co}^{2+}$, while for a wider temperature range, it would be better to consider the addition of $\mathrm{Ca}^{2+}$. The cycle life of the electrode containing $\mathrm{Zn}^{2+}$ was improved obviously because there was less electrode swelling due to much reduced formation of $\gamma-\mathrm{NiOOH}$.

(c) 1999 The Electrochemical Society. S0013-4651(99)03-064-5. All rights reserved.
\end{abstract}

Manuscript submitted March 16, 1999; revised manuscript received May 7, 1999.

Nickel hydroxide is widely used as an active material in nickel electrodes. ${ }^{1-3}$ The high power density, very good cyclability, and high specific energy of these electrodes make them very competitive for an extended range of applications. ${ }^{4,5}$ The most recent application of nickel electrodes is in nickel-metal hydride (Ni-MH) batteries. In current designs of rechargeable batteries containing nickel electrodes, the battery capacity is generally limited by the nickel electrode for reasons of battery safety. ${ }^{6}$ It follows that increasing the energy density of the nickel hydroxide electrode is essential to raise the energy density of such batteries.

It is reported that there are four phases produced over the lifetime of a nickel hydroxide electrode, namely, $\beta-\mathrm{Ni}(\mathrm{OH})_{2}, \beta-\mathrm{NiOOH}, \gamma-$ $\mathrm{NiOOH}$, and $\alpha-\mathrm{Ni}(\mathrm{OH})_{2} .{ }^{7}$ The formation of $\gamma-\mathrm{NiOOH}$ is associated with the volume expansion or swelling of the nickel hydroxide electrode. The phase change from $\beta-\mathrm{NiOOH}$ to $\gamma-\mathrm{NiOOH}$ can be correlated to a $44 \%$ increase in volume. Therefore, during the charge-discharge processes, it is observed that (i) the thickness of the nickel hydroxide electrode is increased and (ii) the surface area of the nickel hydroxide electrode is increased. ${ }^{8}$ The expansion of the active material interferes with the effective contact between particles of the active material, and this increases the resistance of the electrode reaction, especially for high rate or high temperature charge-discharge.

To improve the characteristics of the nickel hydroxide electrode, much work has been focused on the development of spherical $\mathrm{Ni}(\mathrm{OH})_{2}$ powder ${ }^{9,10}$ and additives. ${ }^{11-14}$ Spherical nickel hydroxide powder, which suppresses the development of the inner pore volume, makes it possible to increase the density of the active material itself. Nickel hydroxide powders currently utilized in the nickel electrodes require cobalt or cobalt oxides to make them viable and attractive. ${ }^{15}$ The addition of calcium compound is very useful to improve the charging efficiency of the nickel electrodes. ${ }^{16}$ The addition of several percent of $\mathrm{Cd}, \mathrm{Zn}$, or other elements as solid solutions to the nickel hydroxide is a very effective method of suppressing the formation of $\gamma-\mathrm{NiOOH} .{ }^{9}$ Although there are numerous studies on these topics, the results are still not complete. It is also noted that Co is very expensive and that $\mathrm{Cd}$ causes environmental pollution. Thus, their utilization limits further development of so-called green $\mathrm{Ni}$ $\mathrm{MH}$ batteries.

In the present work, high density spherical nickel hydroxide powder was prepared. The influence of preparation conditions and the additions such as $\mathrm{Ca}^{2+}, \mathrm{Co}^{2+}$, and $\mathrm{Zn}^{2+}$ on the characteristics of the electrodes was also studied for the purpose of increasing the elec-

\footnotetext{
* Electrochemical Society Student Member.

** Electrochemical Society Active Member.

z E-mail: hua_liu@uow.edu.au
}

trochemical activity of the active material. Powder A was prepared by the conventional method. Powders B, C, D, and E were prepared by using a spraying technique, which contained, respectively, no additive, $3.0 \mathrm{wt} \% \mathrm{Ca}^{2+}, 3.5 \mathrm{wt} \% \mathrm{Co}^{2+}$, and $3.6 \mathrm{wt} \% \mathrm{Zn}^{2+}$.

\section{Experimental}

Nickel hydroxide powders. - High density nickel hydroxide powder was synthesized using an automated Yamato Pulvis mini-spray instrument (model GA-32) as shown schematically in Fig. 1. The coprecipitation process involves $(i)$ mixing the aqueous solution of nickel sulfate and chlorides of the additives calcium, cobalt, or zinc (each up to $6 \mathrm{wt} \%$ ); (ii) adding ammonia solution to the above mixture to form the ammine complex; and (iii) spraying the ammine complex in a heated atmosphere through a nozzle and injecting an aqueous solution of potassium hydroxide to precipitate spherical nickel hydroxides, which contain different amounts of $\mathrm{Ca}(\mathrm{OH})_{2}$, $\mathrm{Co}(\mathrm{OH})_{2}$, and $\mathrm{Zn}(\mathrm{OH})_{2}$ additives. The solid particles were redispersed in deionized water and dried quickly to get the final powders. For comparison, conventional nickel hydroxide powder was synthesized at room temperature by adding an ammonia solution to a nickel sulfate solution, and then aging in $6 \mathrm{M} \mathrm{KOH}$ solution.

Nickel hydroxide electrodes.-Nickel hydroxide electrodes were prepared by inserting an active paste into a nickel foam plate ( $2.5 \mathrm{~mm}$ thick). A paste containing $85 \mathrm{wt} \%$ nickel hydroxide and

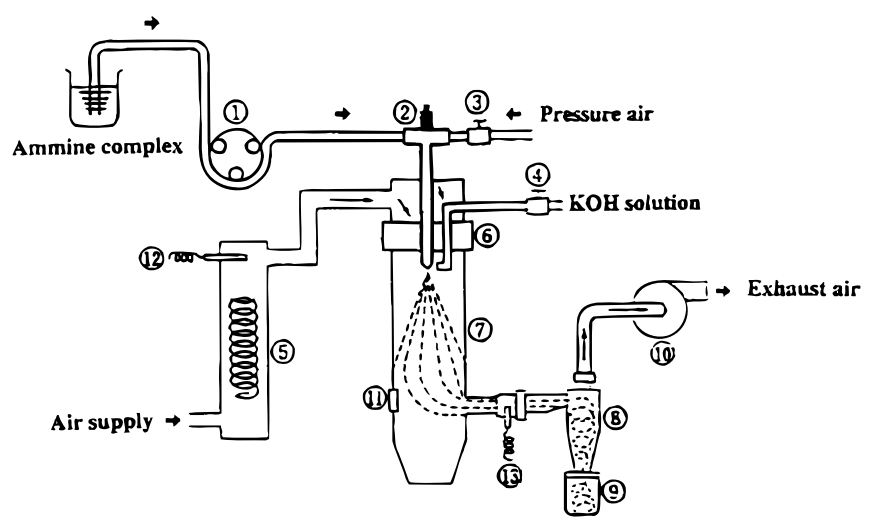

Figure 1. Schematic diagram showing the synthesis of nickel hydroxide powders with high density. (1) Fluid pump, (2) spray nozzle, (3) needle valve, (4) electromagnetic valve, (5) heater, (6) distributor, (7) drying chamber, (8) cyclone, (9) product vessel, (10) aspirator, (11) cap, (12) temperature sensor, and (13) outlet temperature sensor. 
15 wt \% nickel powder as electronic binder was used. These electrodes were dried at $100^{\circ} \mathrm{C}$ for $1 \mathrm{~h}$ and cut into disks $(1.2 \times 1.2 \mathrm{~cm})$ which were pressed at a pressure of $82 \mathrm{MPa}$.

Electrode measurement.-The nickel hydroxide electrode was spot-welded to a nickel wire for electrical connection. Electrode property measurements were carried out at controlled temperature by using a divided electrochemical cell which contained the nickel hydroxide working electrode, a metal hydride electrode, a $\mathrm{Hg} / \mathrm{HgO}$ reference electrode, and $6 \mathrm{M} \mathrm{KOH}$ solution as the electrolyte.

Charge-discharge properties of electrodes were measured by use of an automatic charge-discharge unit (DEC-1) and a computer. The examined electrode was galvanostatically charged at $0.2 \mathrm{C}$ rate to $150 \%$ of the theoretical capacity, rested for $0.2 \mathrm{~h}$, and then discharged at different discharge currents to $0.1 \mathrm{~V}$ vs. $\mathrm{Hg} / \mathrm{HgO}$ electrode. Cycle tests were conducted under the following scheme: charge at $150 \mathrm{~mA} / \mathrm{g}$ for $2.5 \mathrm{~h}$, rest for $0.2 \mathrm{~h}$, and discharge at $150 \mathrm{~mA} / \mathrm{g}$ to $0.1 \mathrm{~V} v s$. $\mathrm{Hg} / \mathrm{HgO}$ electrode. The swelling of the electrodes was measured using a thickness gauge which is capable of continuous examination of the charge and discharge cycles. The discharge capacity of the nickel hydroxide in the positive electrode was based on the amount of the active material $\left[\mathrm{Ni}(\mathrm{OH})_{2}\right]$ not including the weight of the conductive nickel powder and the additives in the electrodes. The utilization of the active material $\mathrm{Ni}(\mathrm{OH})_{2}$ was calculated from the ratio of the actual discharge capacity of $\mathrm{Ni}(\mathrm{OH})_{2}$ in each electrode to the theoretical capacity $(289 \mathrm{mAh} / \mathrm{g})$. The discharge capacity of each electrode was expressed in $\mathrm{mAh}$ per gram of the active material.

The cyclic voltammetry (CV) measurements were recorded using a potentiostat (EG\&G Princeton Applied Research, M362) with a potential scan rate of $1 \mathrm{mV} / \mathrm{s}$. The switching potentials were 0.1 to $0.6 \mathrm{~V} v s . \mathrm{Hg} / \mathrm{HgO}$ electrode.

Physical and chemical analyses.-The pore size distribution and inner pore volume of nickel hydroxide powders were measured by a NOVA 1000 (Yuasa Ionics) nitrogen adsorption analyzer. Thermal analysis was carried out with a TGA-92-16-18 (Setaram) thermal analyzer. The chemical compositions of the nickel hydroxide were obtained using an inductively coupled plasma (ICP) emission spectrophotometer (model P-5200 from Hitachi Ltd). The phase structure was identified by a Philips PW1010 X-ray diffractometer (XRD) with $\mathrm{Cu} \mathrm{K} \alpha$ radiation. Surface images were investigated by a Leica/Cambridge Stereoscan 440 scanning electron microscope (SEM).

\section{Results and Discussion \\ Preparation Processes}

Effect of $p H$.- The properties of nickel hydroxide powders prepared at different $\mathrm{pH}$ values under given conditions are summarized in Table I. Both the tapping density and the discharge capacity of the nickel hydroxide gradually increased with increasing $\mathrm{pH}$ value, and reached a maximum at $\mathrm{pH} 11.0$, and then decreased.

Effect of nickel salts. - The characteristics of nickel hydroxide powders prepared from different nickel salts are given in Table II. The results illustrate that the electrochemical activity of nickel hydroxide synthesized from $\mathrm{NiSO}_{4}$ is higher than that of the others prepared from $\mathrm{Ni}\left(\mathrm{NO}_{3}\right)_{2}$ and $\mathrm{NiCl}_{2}$. The reason is that the adsorption of $\mathrm{SO}_{4}^{2-}$ ions facilitates the precipitation, and this behavior decreased the quantity of adsorbed impurities on the nickel hydroxide powders. ${ }^{17}$ As a result, the crystal structure of nickel hydroxide favors the powder activity.

Effect of drying temperature.-Table III illustrates the influence of drying temperature on the properties of nickel hydroxide powders. The electrochemical performance is excellent when the drying temperatures are in the range of $80-120^{\circ} \mathrm{C}$. According to a previous report, ${ }^{18}$ there are two kinds of water molecules in nickel hydroxide, namely, the adsorbed (ad) water and the structural (st) water. The loss of adsorbed water molecules takes place between 50 and $90^{\circ} \mathrm{C}$,
Table I. Effect of solution $\mathrm{pH}$ on the performance of $\mathrm{Ni}(\mathrm{OH})_{2} \cdot{ }^{\mathrm{a}}$

\begin{tabular}{cccc}
$\mathrm{pH}$ value & $\begin{array}{c}\text { Tapping } \\
\text { density } \\
\left(\mathrm{g} / \mathrm{cm}^{3}\right)\end{array}$ & $\begin{array}{c}\text { Discharge } \\
\text { capacity } \\
(\mathrm{mAh} / \mathrm{g})\end{array}$ & $\begin{array}{c}\text { Specific } \\
\text { capacity } \\
\left(\mathrm{mAh} / \mathrm{cm}^{3}\right)\end{array}$ \\
\hline 9.5 & 1.85 & 242 & 448 \\
10.0 & 1.98 & 253 & 501 \\
10.5 & 2.12 & 260 & 551 \\
11.0 & 2.23 & 262 & 584 \\
11.5 & 2.16 & 257 & 555 \\
12.0 & 2.07 & 251 & 520
\end{tabular}

a The nickel salt of $\mathrm{NiSO}_{4}$ is used, and the drying temperature is $100^{\circ} \mathrm{C}$.

\begin{tabular}{lccc}
\hline $\begin{array}{c}\text { Table II. Effect of nickel salts on the properties of nickel } \\
\text { hydroxide. }\end{array}$ & \\
Nickel salts & $\begin{array}{c}\text { Tapping density } \\
\left(\mathrm{g} / \mathrm{cm}^{3}\right)\end{array}$ & $\begin{array}{c}\text { Discharge capacity } \\
(\mathrm{mAh} / \mathrm{g})\end{array}$ & $\begin{array}{c}\text { Specific capacity } \\
\left(\mathrm{mAh} / \mathrm{cm}^{3}\right)\end{array}$ \\
\hline $\mathrm{Ni}^{2}\left(\mathrm{NO}_{3}\right)_{2}$ & 2.16 & 254 & 549 \\
$\mathrm{NiCl}_{2}$ & 2.09 & 246 & 514 \\
$\mathrm{NiSO}_{4}$ & 2.23 & 262 & 584 \\
\hline
\end{tabular}

a The solution $\mathrm{pH}$ is 11.0 and the drying temperature is $100^{\circ} \mathrm{C}$.

whereas structural water is removed between 90 and $180^{\circ} \mathrm{C}$. The processes for water removal are illustrated as follows

$$
\begin{gathered}
\mathrm{Ni}(\mathrm{OH})_{2} \cdot\left(X_{\mathrm{ad}}+Y_{\mathrm{st}}\right) \mathrm{H}_{2} \mathrm{O} \stackrel{50-90^{\circ} \mathrm{C}}{\longrightarrow} \mathrm{Ni}(\mathrm{OH})_{2} \cdot Y_{\mathrm{st}} \mathrm{H}_{2} \mathrm{O}+X \mathrm{H}_{2} \mathrm{O} \\
\mathrm{Ni}(\mathrm{OH})_{2} \cdot Y_{\mathrm{st}} \mathrm{H}_{2} \mathrm{O} \stackrel{90-180^{\circ} \mathrm{C}}{\longrightarrow} \mathrm{Ni}(\mathrm{OH})_{2}+Y_{2} \mathrm{O} \\
\mathrm{Ni}(\mathrm{OH})_{2} \stackrel{>180^{\circ} \mathrm{C}}{\longrightarrow} \mathrm{NiO}+\mathrm{H}_{2} \mathrm{O}
\end{gathered}
$$

The nickel hydroxide dried at low temperatures contains more structural water and has high electrochemical activity because structural water favors the rate of diffusion of protons. However, drying at a low temperature is too slow. On the basis of the above data, and taking into account the electrochemical activity, the drying temperature is chosen in the range of $100-120^{\circ} \mathrm{C}$. The final powders should be nickel hydroxide particles strongly bonded by structural water molecules.

\section{Physical and Chemical Properties of Nickel Hydroxide Powders}

Composition.-The chemical compositions for nickel hydroxide powders are given in Table IV. The nickel contents are higher in A and $\mathrm{B}$ powders because there were no additions made during the

\begin{tabular}{|c|c|c|c|}
\hline $\begin{array}{c}\text { Drying } \\
\text { temperature } \\
\left({ }^{\circ} \mathrm{C}\right)\end{array}$ & $\begin{array}{l}\text { Tapping density } \\
\left(\mathrm{g} / \mathrm{cm}^{3}\right)\end{array}$ & $\begin{array}{l}\text { Discharge capacity } \\
\qquad(\mathrm{mAh} / \mathrm{g})\end{array}$ & $\begin{array}{l}\text { Specific capacity } \\
\left(\mathrm{mAh} / \mathrm{cm}^{3}\right)\end{array}$ \\
\hline 50 & 2.24 & 259 & 580 \\
\hline 80 & 2.23 & 262 & 584 \\
\hline 100 & 2.21 & 260 & 575 \\
\hline 120 & 2.17 & 256 & 556 \\
\hline 130 & 2.12 & 251 & 532 \\
\hline
\end{tabular}
preparation process. The nickel contents are very similar in the other powders, but the additive contents are different. 


\begin{tabular}{|c|c|c|c|c|c|}
\hline \multirow{2}{*}{$\begin{array}{l}\text { Chemical } \\
\text { composition } \\
\text { (wt \%) }\end{array}$} & \multicolumn{5}{|c|}{ Powders } \\
\hline & A & B & $\mathrm{C}$ & $\mathrm{D}$ & E \\
\hline $\mathrm{Ni}$ & 62.4 & 62.3 & 58.8 & 58.6 & 58.5 \\
\hline $\mathrm{Ca}$ & & & 2.9 & & \\
\hline Co & & & & 3.4 & \\
\hline $\mathrm{Zn}$ & & & & & 3.5 \\
\hline
\end{tabular}

Surface image.-The surface images of the A and B powders were analyzed by SEM and are shown in Fig. 2. At low magnification, powder A consists of irregular particles with an average particle size of $20 \mu \mathrm{m}$, while powder B appears as comparatively uniform spheres with an average diam of about $15 \mu \mathrm{m}$. At high magnification, powder A shows many pores on the powder surface; however, the surface of powder B is quite smooth. It was also observed that powders $\mathrm{C}, \mathrm{D}$, and $\mathrm{E}$ had similar surface images to that of powder $\mathrm{B}$; thus, they are not shown.

Pore size and pore volume.-The pore size distribution and pore volume of all the nickel hydroxide powders studied are listed in Table V. The conventional powder has a wide range of pores with radii between 8 and $180 \AA$, and this results in an average pore volume of $0.14 \mathrm{~mL} / \mathrm{g}$. On the other hand, the spherical powders show a quite narrow range of pore size distribution between 10 and $15 \AA$ and a pore volume of about $0.04 \mathrm{~mL} / \mathrm{g}$. There seems to be no significant effect on the pore size distribution and pore volume of the different additives. The spherical powders show the tapping densities between 2.17 and $2.23 \mathrm{~g} / \mathrm{cm}^{3}$, much higher than that of the conventional powder.

Crystallite size.-Figure 3 shows the XRD patterns of the nickel hydroxide powders. All the peaks can be indexed to pure $\beta-\mathrm{Ni}(\mathrm{OH})_{2}$ phase, illustrating that the added $\mathrm{Ca}^{2+}, \mathrm{Co}^{2+}$, and $\mathrm{Zn}^{2+}$ are incorporated in the lattice of nickel hydroxide. Therefore, the formulae of the powders prepared by adding these metal ions should be written as $(\mathrm{Ni}, \mathrm{Ca})(\mathrm{OH})_{2},(\mathrm{Ni}, \mathrm{Co})(\mathrm{OH})_{2}$, and $(\mathrm{Ni}, \mathrm{Zn})(\mathrm{OH})_{2}$.

Table VI summarizes the full width of half maximum intensity $\left(W_{\mathrm{I} / 2}\right)$ of the respective powders in (001) and (101) lines. It can be seen that the diffraction peak intensity and the $W_{\mathrm{I} / 2}$ values are different for each powder. The $W_{\mathrm{I} / 2}$ value for powder $\mathrm{A}$ is the smallest, while for powder E, it is the largest. This result illustrates that the

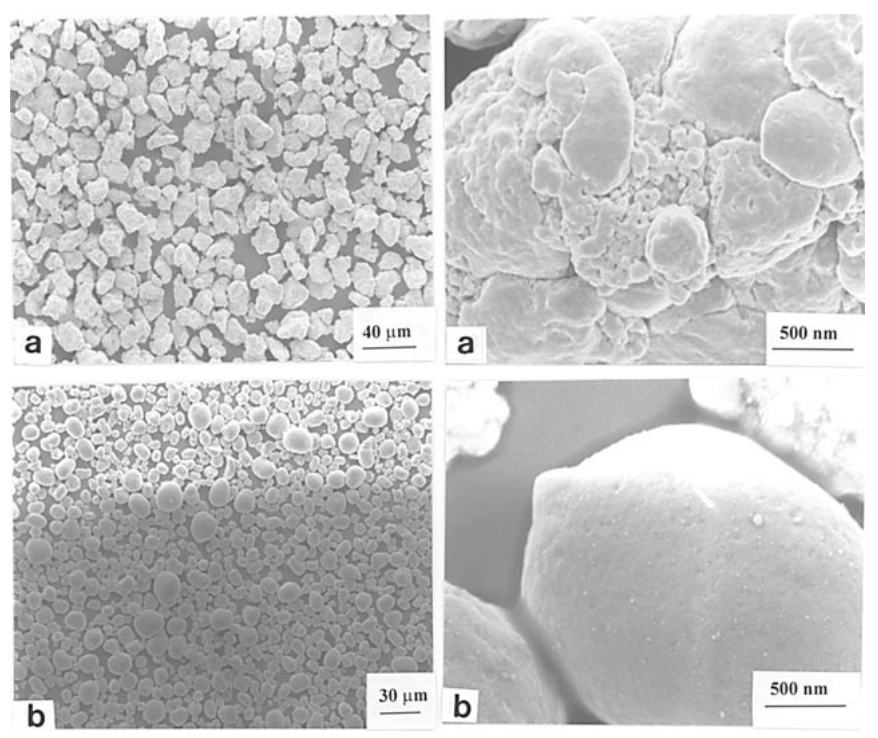

Figure 2. Scanning electron micrographs of (a) the conventional powder A and (b) spherical nickel hydroxide powder B.
Table V. The pore size distribution, inner pore volume, and tapping density of the conventional and high-density nickel hydroxide powders.

\begin{tabular}{cccc} 
Powders & $\begin{array}{c}\text { Pore size } \\
(\AA)\end{array}$ & $\begin{array}{c}\text { Pore volume } \\
(\mathrm{mL} / \mathrm{g})\end{array}$ & $\begin{array}{c}\text { Tapping density } \\
\left(\mathrm{g} / \mathrm{cm}^{3}\right)\end{array}$ \\
\hline A & $8-180$ & 0.14 & 1.62 \\
$\mathrm{~B}$ & $11-15$ & 0.047 & 2.19 \\
$\mathrm{C}$ & $11-14$ & 0.044 & 2.17 \\
$\mathrm{D}$ & $11-14$ & 0.042 & 2.20 \\
$\mathrm{E}$ & $10-14$ & 0.041 & 2.23
\end{tabular}

crystallite size of the nickel hydroxide in powder A is the largest, while that for sample $\mathrm{E}$ is the smallest. ${ }^{19}$ The crystalline size decreases in the order of $\mathrm{A}>\mathrm{B}>\mathrm{C}>\mathrm{D}>\mathrm{E}$.

The differential thermal analysis (DTA) curves of the nickel hydroxide powders are given in Fig. 4. In each sample, a clear endothermic peak was observed around $300^{\circ} \mathrm{C}$, owing to the decomposition of the nickel hydroxide accompanying dehydration. The decomposition temperatures for powders B, C, D, and E are clearly lower than that for powder A. This is consistent with the result from $\mathrm{XRD}$ analysis; that is, powder A, having a larger crystallite size, shows a higher decomposition temperature. This result is in good agreement with the relationship between the decomposition temperature and the crystallite size of nickel hydroxide powders, previously reported by Tirado et al..$^{20}$ and Watanabe et al. ${ }^{21}$

\section{Electrochemical Properties}

Charge-discharge curves.-Figure 5 illustrates the charge-discharge curves of A, B, C, D, and E electrodes in the first cycle. In the charge curves, electrode A shows a higher charging potential than that of any other electrode. From the discharge curves, it can be seen that electrode A has the lowest discharge potential and discharge capacity. Therefore, nickel hydroxide powders with a smaller crystalline size have better charge-discharge characteristics such as lower overpotential (the difference between the charge plateau potential and the discharge plateau potential), higher discharge plateau potential, and higher capacity. Because electrode A shows the poorest charge-discharge properties, it was not selected in the following work.

Cyclic voltammograms.-Figure 6 shows the cyclic voltammograms obtained from different electrodes in the second cycle. The experimental results describing the features of the voltammograms are summarized in Table VII. The difference $\left(E_{\mathrm{O}}-E_{\mathrm{R}}\right)$ between the oxidation potential $\left(E_{\mathrm{O}}\right)$ and the reduction potential $\left(E_{\mathrm{R}}\right)$ is taken as a measure of the reversibility of the electrode reaction. ${ }^{22}$ The smaller is this value, the more reversible is the electrode reaction. Therefore, the reversibility for electrode reaction is greatly improved by the additions of $\mathrm{Ca}^{2+}, \mathrm{Co}^{2+}$, and $\mathrm{Zn}^{2+}$. In particular, the electrode

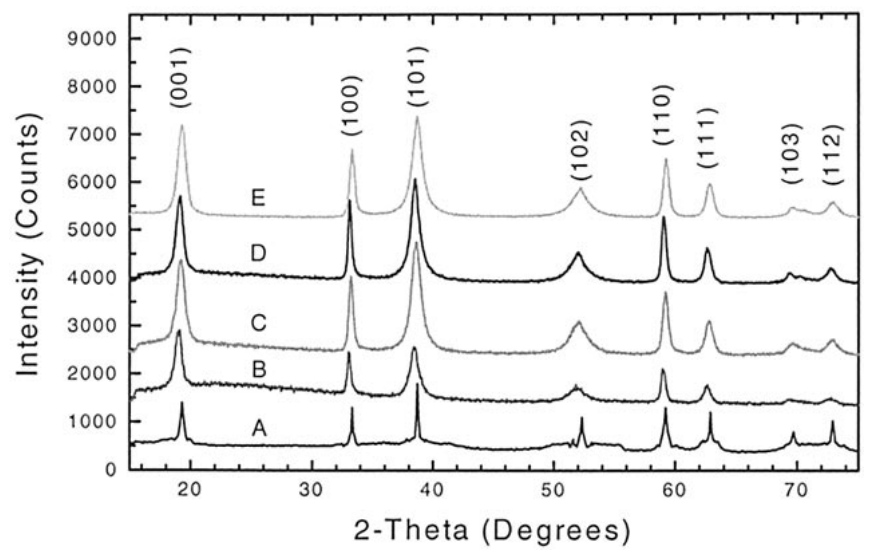

Figure 3. XRD patterns of the nickel hydroxide powders. 
Table VI. The $W_{\mathrm{I} / 2}$ values in (001) and (101) diffraction lines of different nickel hydroxide powders.

\begin{tabular}{ccc} 
& \multicolumn{2}{c}{$\mathrm{W}_{\mathrm{I} / 2}$ values (degrees) } \\
\cline { 2 - 3 } Powder & $(001)$ & $(101)$ \\
$\mathrm{A}$ & 0.406 & 0.294 \\
$\mathrm{~B}$ & 0.788 & 0.895 \\
$\mathrm{C}$ & 0.817 & 0.895 \\
$\mathrm{D}$ & 0.819 & 0.897 \\
$\mathrm{E}$ & 0.822 & 0.902
\end{tabular}

with $\mathrm{Ca}^{2+}$ addition allows the charge process to occur most easily and most reversibly because of its low value of $E_{\mathrm{O}}-E_{\mathrm{R}}$.

On the other hand, the difference $\left(E_{\mathrm{OE}}-E_{\mathrm{O}}\right)$ between the potential of oxygen evolution $\left(E_{\mathrm{OE}}\right)$ and the oxidation potential is an important parameter to judge the properties of nickel electrodes. A large difference is beneficial for the nickel electrodes. The difference between $E_{\mathrm{OE}}$ and $E_{\mathrm{O}}$ increases significantly by the $\mathrm{Ca}^{2+}, \mathrm{Co}^{2+}$, and $\mathrm{Zn}^{2+}$ additions due to the decrease of the oxidation potential and the increase of the oxygen evolution potential. This attribute apparently allows the electrodes with the additives to be charged fully, namely, the complete oxidation of $\mathrm{Ni}^{2+}$ to $\mathrm{Ni}^{3+}$. As a result, the electrodes

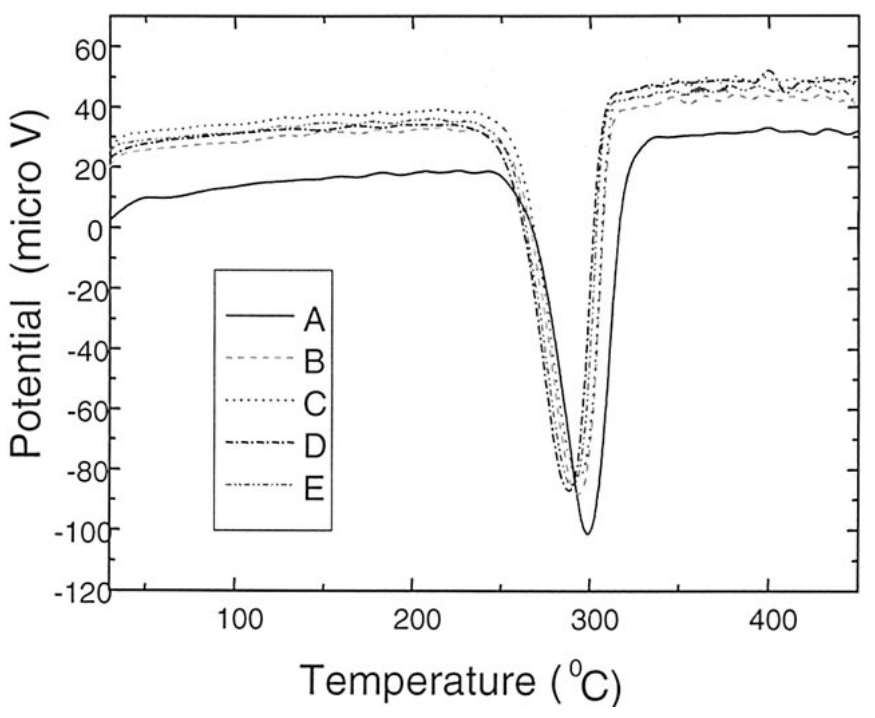

Figure 4. DTA analysis for nickel hydroxide powders.

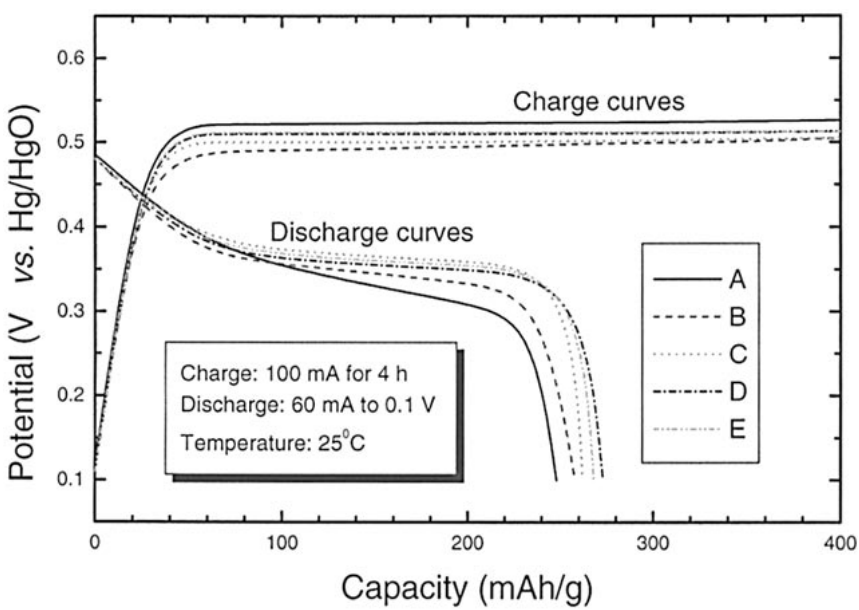

Figure 5. Charge-discharge potentials as a function of the capacity for nickel hydroxide electrodes.

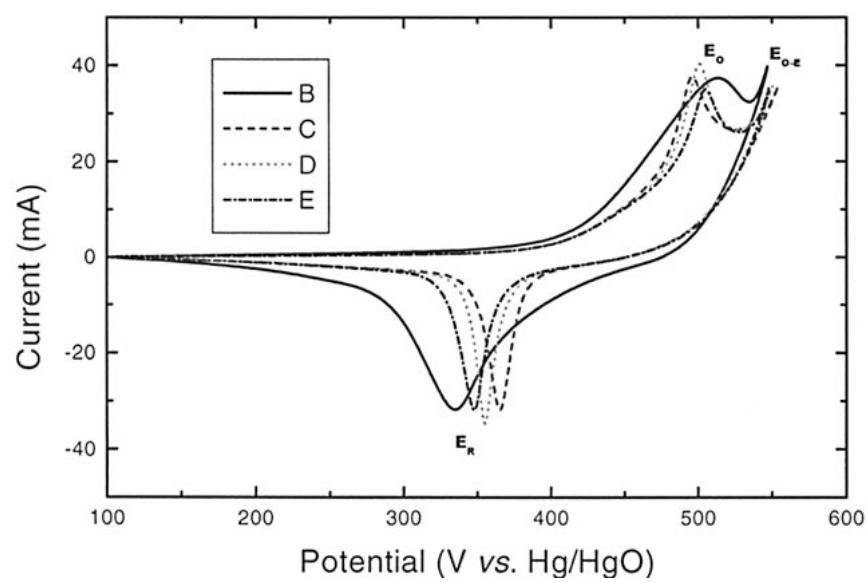

Figure 6. Cyclic voltammograms for various nickel electrodes in the second cycle (scan rate: $1 \mathrm{mV} / \mathrm{s}$ ).

would give better properties such as a higher utilization and a larger capacity, which are described later.

Utilization of nickel hydroxide.-The effect of the conventional (A) and high density nickel hydroxide (B, C, D, E) powders on the percentage utilization are given in Table VIII. The utilization of the $\mathrm{Ni}(\mathrm{OH})_{2}$ electrodes with $\mathrm{Ca}^{2+}, \mathrm{Co}^{2+}$, and $\mathrm{Zn}^{2+}$ added is higher than that of the conventional one. This might be caused by the smaller pore volume of the high-density nickel hydroxide powders prepared through the spraying technique. In addition, the electrode with the Co addition shows the highest utilization, probably due to the improvement in electric conductivity of the electrode because of the formation of conductive $\mathrm{CoOOH} .{ }^{9}$

Influence of additives. - Figure 7 shows the relationship between the utilization of nickel hydroxide electrodes and the amounts of $\mathrm{Ca}(\mathrm{OH})_{2}, \mathrm{Co}(\mathrm{OH})_{2}$, and $\mathrm{Zn}(\mathrm{OH})_{2}$ in the tested half-cells. It can be seen that the results are similar for all three kinds of additives, namely, the higher the amount of the additive added, the higher the utilization of the electrode. The utilization of each electrode saturates

Table VII. Oxidation potential $\left(E_{\mathrm{O}}\right)$, reduction potential $\left(E_{\mathrm{R}}\right)$, oxygen evolving potential $\left(E_{O E}\right)$, the difference between $E_{O}$ and $E_{\mathrm{R}}$, and the difference between $E_{\mathrm{OE}}$ and $E_{\mathrm{O}}$ for various nickel electrodes.

\begin{tabular}{cccccc} 
& \multicolumn{5}{c}{ Potential values } \\
\cline { 2 - 6 } Electrode & $E_{\mathrm{O}}$ & $E_{\mathrm{R}}$ & $E_{\mathrm{OE}}$ & $E_{\mathrm{O}}-E_{\mathrm{R}}$ & $E_{\mathrm{OE}}-E_{\mathrm{O}}$ \\
\hline $\mathrm{B}$ & 515 & 335 & 550 & 180 & 35 \\
$\mathrm{C}$ & 495 & 365 & 559 & 130 & 64 \\
$\mathrm{D}$ & 500 & 355 & 555 & 145 & 55 \\
$\mathrm{E}$ & 504 & 349 & 551 & 155 & 47
\end{tabular}

Table VIII. The utilization of the conventional and high density nickel hydroxide powders at the discharge current density of $50 \mathrm{~mA} / \mathrm{g}$.

\begin{tabular}{cccc} 
& \multicolumn{2}{c}{ Discharge capacity } & Utilization \\
\cline { 2 - 3 } $\mathrm{Ni}(\mathrm{OH})_{2}$ & $(\mathrm{mAh} / \mathrm{g})$ & $\left(\mathrm{mAh} / \mathrm{cm}^{3}\right)$ & $(\%)$ \\
\hline $\mathrm{A}$ & 207 & 335 & 71.6 \\
$\mathrm{~B}$ & 267 & 585 & 92.4 \\
$\mathrm{C}$ & 270 & 590 & 93.4 \\
$\mathrm{D}$ & 278 & 612 & 96.2 \\
$\mathrm{E}$ & 272 & 602 & 94.1
\end{tabular}




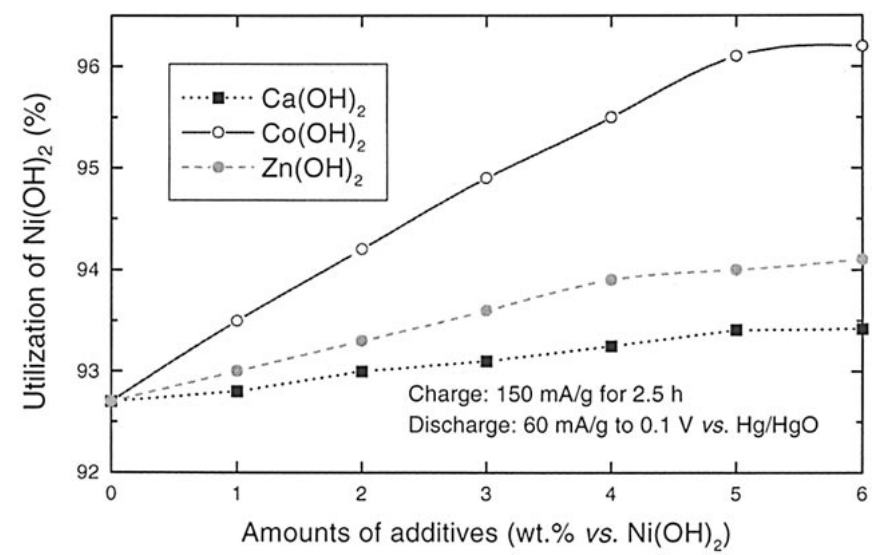

Figure 7. Utilization of $\mathrm{Ni}(\mathrm{OH})_{2}$ with different amounts of $\mathrm{Ca}(\mathrm{OH})_{2}$, $\mathrm{Co}(\mathrm{OH})_{2}$, and $\mathrm{Zn}(\mathrm{OH})_{2}$.

above 5 wt \%. The sequence of $\mathrm{Ni}(\mathrm{OH})_{2}$ utilization is: $\mathrm{Co}(\mathrm{OH})_{2}>$ $\mathrm{Zn}(\mathrm{OH})_{2}>\mathrm{Ca}(\mathrm{OH})_{2}$. The high utilization of $\mathrm{Ni}(\mathrm{OH})_{2}$ containing $\mathrm{Co}^{2+}$ may be the reason that cobalt oxides/hydroxides are widely chosen as additives in nickel electrodes.

Influence of discharge current.-Figure 8 presents the effect of the discharge current on the utilization of active materials. All charge operations were conducted at $150 \mathrm{~mA} / \mathrm{g}$ for $2.5 \mathrm{~h}$. The utilization of each electrode decreases obviously with increase in the discharge current. In all cases, the electrode with $5 \mathrm{wt} \% \mathrm{Co}(\mathrm{OH})_{2}$ shows a higher utilization than that of the other two electrodes; therefore, the dischargeability of the nickel electrode at high discharge current is effectively improved by the addition of $\mathrm{Co}^{2+}$ ions.

Influence of temperature.-In practical application, nickel electrodes should have a stable discharge capacity at a wide temperature range. The utilization of a nickel electrode is generally lowered at high temperature due to the oxygen evolution as illustrated in Eq. 4

$$
4 \mathrm{OH}^{-} \rightarrow 2 \mathrm{H}_{2} \mathrm{O}+\mathrm{O}_{2}+4 \mathrm{e}^{-}
$$

Figure 9 gives the relationship between the utilization and temperature of various nickel hydroxide electrodes. The utilization of these electrodes decreases obviously with increase in the working temperature. The utilization of a nickel electrode containing a $\mathrm{Ca}^{2+}$ addition at $60^{\circ} \mathrm{C}$ shows the decrease in the smallest amount, which results from the largest difference between the potential of oxygen evolution and the oxidation potential. This fact reveals clearly that the addition of $\mathrm{Ca}^{2+}$ is useful to improve the charge-discharge properties of the nickel electrode at high temperatures such as at $60^{\circ} \mathrm{C}$.

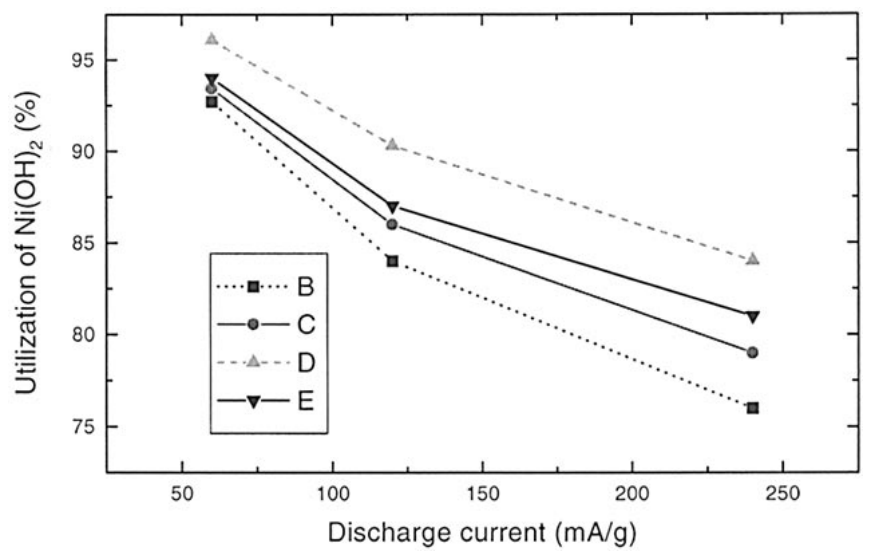

Figure 8. Utilization of $\mathrm{Ni}(\mathrm{OH})_{2}$ at different discharge currents for electrodes $\mathrm{B}, \mathrm{C}, \mathrm{D}$, and $\mathrm{E}$.

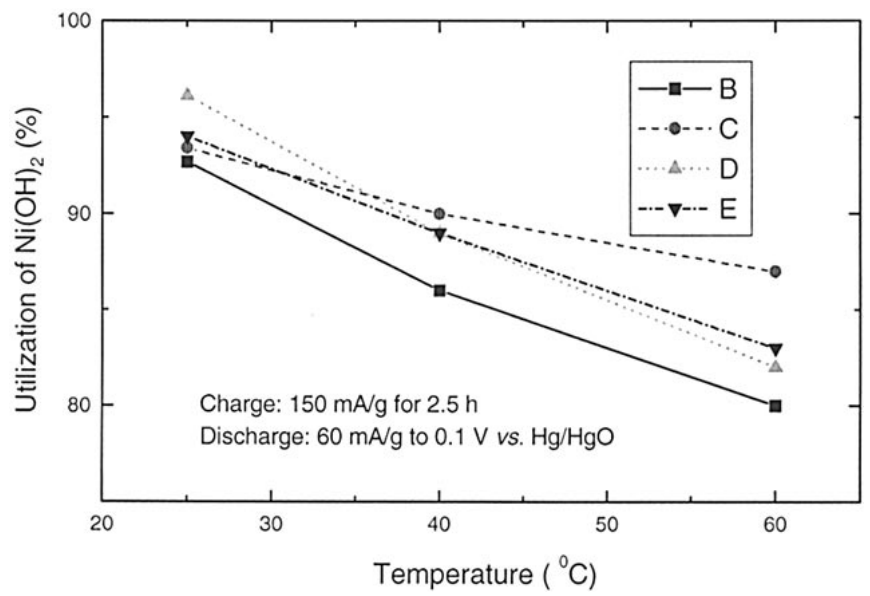

Figure 9. Utilization of B, C, D, and E electrodes at different temperatures.

Cycle life.-Figure 10 shows the cycle lives of electrodes B, C, $\mathrm{D}$, and $\mathrm{E}$. The results illustrate that the cycle lives of the electrodes are related to the kinds of the additives: the longest cycle life was achieved for the electrode containing $\mathrm{Zn}^{2+}$ additive. For example, after 200 charge-discharge cycles (100\% depth of discharge, DOD), the electrode still kept $95 \%$ of the initial capacity, much higher than that of any other electrode.

Since electrode swelling is a cause of a low electrode cycle life, the alteration of the electrode thickness after different numbers of cycles was measured, as shown in Fig. 11. Without any additive, the electrode thickness expanded about $18 \%$ after 75 cycles. However, in any case with the additive, the electrode swelling decreased greatly. Especially by adding $\mathrm{Zn}^{2+}$, the electrode thickness increased only $2 \%$ after the same cycles. Therefore, the cycle life of the electrode can be correlated with the electrode expansion: the greater is the electrode swelling, the faster is the capacity decay of the electrode.

Formation of $\gamma$-NiOOH.-To explore further the factors which have an effect on the electrode cycle life and the electrode swelling, the active material in each electrode after fully charging at the 200th cycle was analyzed by XRD. The results are shown in Fig. 12. It is noted that there is not only $\beta-\mathrm{NiOOH}$ phase but also $\gamma-\mathrm{NiOOH}$ phase found in electrode $\mathrm{B}$ (the pure nickel hydroxide electrode). However, there is much less $\gamma-\mathrm{NiOOH}$ detected in electrodes $\mathrm{C}, \mathrm{D}$, and $\mathrm{E}$ (with the additions of $\mathrm{Ca}^{2+}, \mathrm{Co}^{2+}$, and $\mathrm{Zn}^{2+}$ ), and the active materials exist mostly in the form of $\beta-\mathrm{NiOOH}$. This is most obvious for the electrode containing added $\mathrm{Zn}^{2+}$.

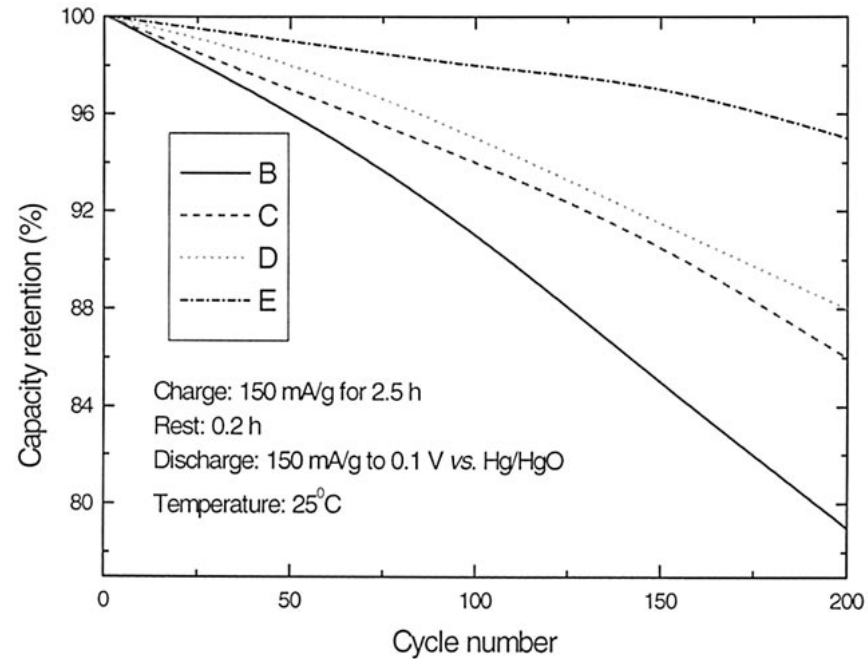

Figure 10. Cycle life of the B, C, D, and E electrodes. 


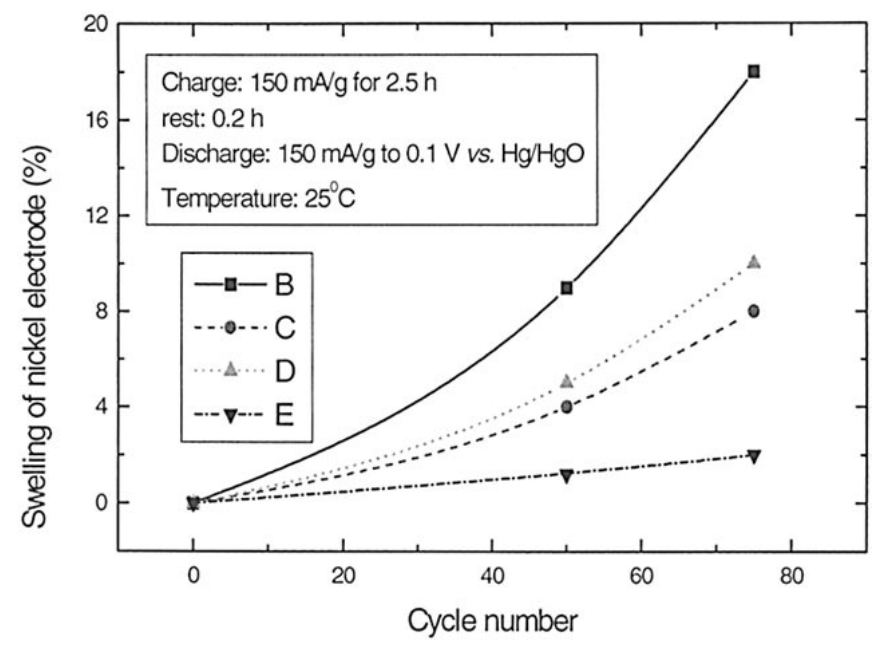

Figure 11. Swelling rate of B, C, D, and E electrodes.

To examine the formation of $\gamma-\mathrm{NiOOH}$ during the charge process, a study was carried out for $\mathrm{B}, \mathrm{C}, \mathrm{D}$, and $\mathrm{E}$ electrodes at the following depths of charge (DOC): (i) $0 \%$, (ii) 25\%, (iii) 50\%, (iv) $75 \%$, (v) $100 \%$, and (vi) $150 \%$. The distribution of the active materials is illustrated in Fig. 13. At $0 \%$ DOC, which is a fully discharged state, the amount of $\beta-\mathrm{Ni}(\mathrm{OH})_{2}$ was $100 \%$ and no $\beta-\mathrm{NiOOH}$ or $\gamma$ $\mathrm{NiOOH}$ was found. When the electrodes were charged, $\beta-\mathrm{Ni}(\mathrm{OH})_{2}$ transformed to $\beta-\mathrm{NiOOH}$ and $\gamma-\mathrm{NiOOH}$. But the ratio for $\beta-\mathrm{NiOOH}$ and $\gamma-\mathrm{NiOOH}$ was quite different. For example, at $150 \%$ DOC, which is a fully charged state, the $\beta-\mathrm{Ni}(\mathrm{OH})_{2}$ in electrode B was transformed to $75 \% \beta-\mathrm{NiOOH}$ and $25 \% \gamma-\mathrm{NiOOH}$. As a comparison, in electrode $\mathrm{E}, \beta-\mathrm{Ni}(\mathrm{OH})_{2}$ was mainly changed to $\beta-\mathrm{NiOOH}$ $(96 \%)$, and only $4 \% \gamma-\mathrm{NiOOH}$ was observed. Thus, it can be concluded that $(i)$ the addition of $\mathrm{Zn}^{2+}$ in the nickel hydroxide electrode can suppress the formation of $\gamma-\mathrm{NiOOH}$ during the charging process; (ii) the formation of $\gamma-\mathrm{NiOOH}$ is very slow at the initial stage of the charging (before 50\% DOC) and quite fast at the end of the charging process (after $50 \%$ DOC).

Change of $\gamma-\mathrm{NiOOH}$.- Phase transformation of $\gamma-\mathrm{NiOOH}$ and $\beta-\mathrm{NiOOH}$ to $\beta-\mathrm{Ni}(\mathrm{OH})_{2}$ was also observed at different DOD. Figure 14 shows their distributions in the electrodes after $0 \%, 25 \%$, $50 \%$, and $100 \%$ DOD. At $0 \%$ DOD, namely, in the fully charged state, the amount of $\gamma-\mathrm{NiOOH}$ was $24 \%, 8 \%, 9 \%$, and $4 \%$, respectively, for B, C, D, and E electrodes. At $50 \%$ DOD, only $2 \% \gamma$ $\mathrm{NiOOH}$ was left in electrode $\mathrm{B}$, and even less remained in electrodes

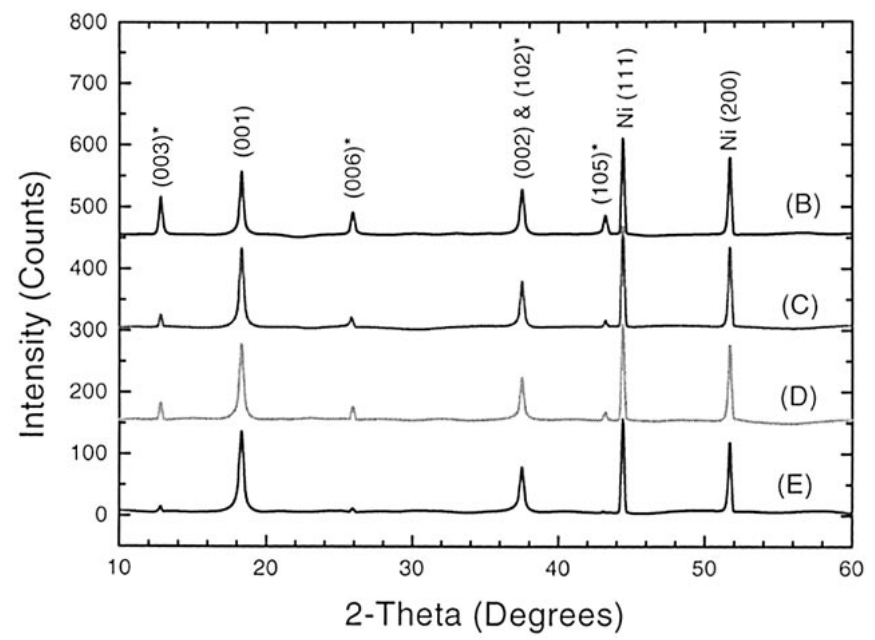

Figure 12. XRD patterns for B, C, D, and E electrodes after fully charging at the 200th cycle $(* \gamma-\mathrm{NiOOH})$.

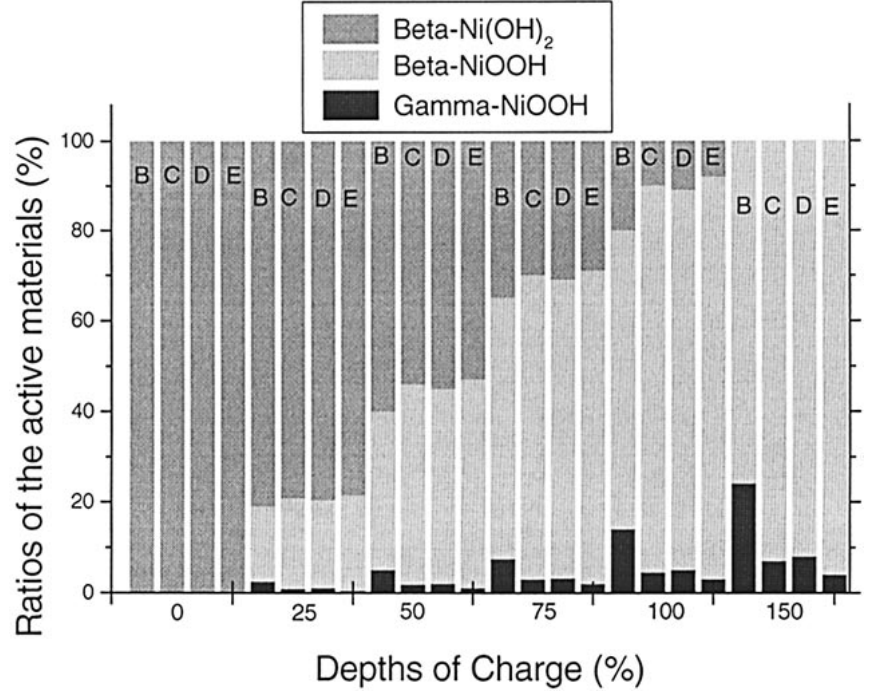

Figure 13. Distribution of the active materials in B, C, D, and E electrodes during different DOCs.

$\mathrm{C}, \mathrm{D}$, and $\mathrm{E}$. No signs of $\gamma-\mathrm{NiOOH}$ were detected in all the electrodes after $100 \%$ DOD. This means that all of the $\gamma-\mathrm{NiOOH}$ formed in the charging process was transformed to $\beta-\mathrm{Ni}(\mathrm{OH})_{2}$ after $100 \%$ DOD. Although the phase transformation between $\gamma-\mathrm{NiOOH}$ and $\beta$ $\mathrm{Ni}(\mathrm{OH})_{2}$ might be associated with a higher oxidation state which can give higher capacities, ${ }^{23}$ it causes a serious volume expansion of the active material, and this results in the swelling of the electrode. Therefore, the formation of $\gamma-\mathrm{NiOOH}$ should be suppressed effectively in practical use, and the addition of $\mathrm{Zn}(\mathrm{OH})_{2}$ to the electrode is obviously an effective way of achieving this result.

\section{Conclusions}

Nickel hydroxide powders having improved properties were prepared by a spraying technique. The influence of the preparation conditions and the coprecipitation of $\mathrm{Ca}^{2+}, \mathrm{Co}^{2+}$, and $\mathrm{Zn}^{2+}$ in the powders on the physical and electrochemical properties were examined. The optimum conditions for preparing powders with spherical particles, high tapping density $\left(2.15\right.$ to $\left.2.23 \mathrm{~g} / \mathrm{cm}^{3}\right)$, small pore volume (about $0.04 \mathrm{~mL} / \mathrm{g}$ ), and excellent activity require the use of $\mathrm{NiSO}_{4}$ as the nickel salt, a reaction $\mathrm{pH}$ of 11.0, and a drying temperature range of 100 to $120^{\circ} \mathrm{C}$.

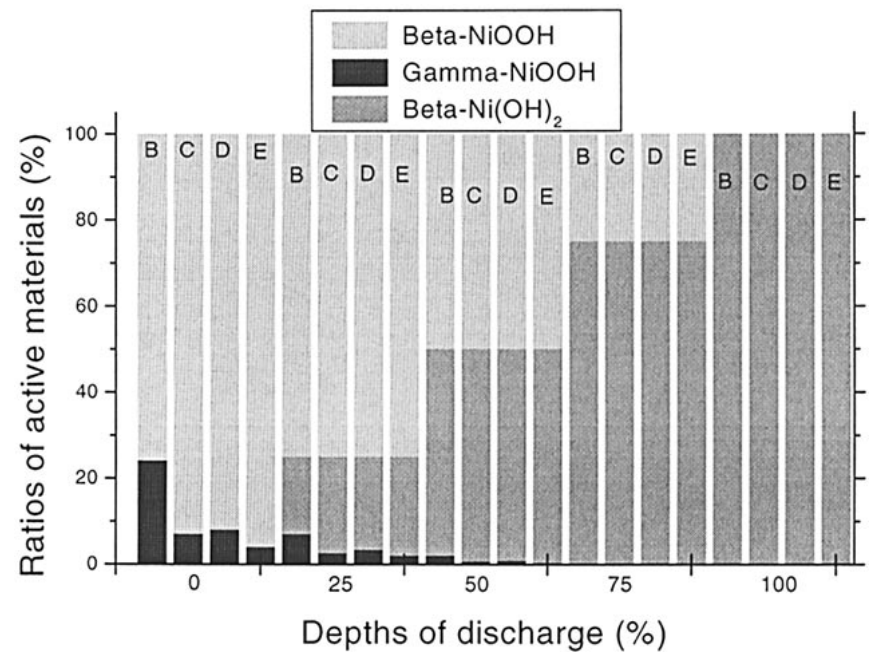

Figure 14. Distribution of the active material in B, C, D, and E electrodes at different DODs. 
By coprecipitating the $\mathrm{Ca}^{2+}, \mathrm{Co}^{2+}$, and $\mathrm{Zn}^{2+}$ in the reactants, the final powders prepared are in the forms of $(\mathrm{Ni}, \mathrm{Ca})(\mathrm{OH})_{2},(\mathrm{Ni}$, $\mathrm{Co})(\mathrm{OH})_{2}$, and $(\mathrm{Ni}, \mathrm{Zn})(\mathrm{OH})_{2}$, having a smaller crystallite size than that of the conventional powder. Nickel hydroxide powders with a smaller crystallite size show better charge-discharge characteristics such as lower overpotential, higher plateau discharge potential, and higher capacity.

At $25^{\circ} \mathrm{C}$, the utilization of $\mathrm{Ni}(\mathrm{OH})_{2}$ with additives of $\mathrm{Ca}^{2+}, \mathrm{Co}^{2+}$, and $\mathrm{Zn}^{2+}$ is in the order of $\mathrm{Co}(\mathrm{OH})_{2}>\mathrm{Zn}(\mathrm{OH})_{2}>\mathrm{Ca}(\mathrm{OH})_{2}$. The higher utilization of $\mathrm{Co}^{2+}$ addition is due to the improvement in electric conductivity of the electrode because of the formation of conductive $\mathrm{CoOOH}$ during the charging process. At higher temperature $\left(60^{\circ} \mathrm{C}\right)$, the nickel electrode containing $\mathrm{Ca}^{2+}$ shows the highest utilization because of the largest difference between the potential of oxygen evolution and the oxidation potential. These results illustrate that for general use it is better to adopt the addition of $\mathrm{Co}^{2+}$, while for a wider temperature range, such as the application of electric vehicles, it would be better to consider the addition of $\mathrm{Ca}^{2+}$ in the active material.

The electrode swelling and cycle life are related to the formation of $\gamma-\mathrm{NiOOH}$; the larger the amount of $\gamma-\mathrm{NiOOH}$ phase formed in the charging process, the greater is the increase of the electrode swelling and also the faster is the capacity decay of the electrode. The $\gamma-\mathrm{NiOOH}$ is mainly formed at the end of the charging process, and it is also completely changed to $\beta-\mathrm{Ni}(\mathrm{OH})_{2}$ at the end of discharge. The addition of $\mathrm{Zn}^{2+}$ in the active material is very effective in suppressing the formation of $\gamma-\mathrm{NiOOH}$. Therefore, this could enable the manufacture of electrodes with longer cycle life.

\section{Acknowledgments}

The authors would like to thank the Department of Employment, Education, and Training (DEET), Australia for financial support.

The University of Wollongong assisted in meeting the publication costs of this article.

\section{References}

1. C. Delmas, C. Faure, L. Gautier, L. G. Demourgues, and A. Rougier, Philos. Trans. R. Soc. London, Ser. A, 354, 1545 (1996).

2. G. Halpert, in Nickel Hydroxide Electrodes, D. A. Corrigan and A. H. Zimmerman, Editors, PV 90-4, p. 1, The Electrochemical Society Proceedings Series, Pennington, NJ (1990).

3. J. McBreen, in Modern Aspects of Electrochemistry, Vol. 21, R. E. White, J. O'M Bockris, and B. E. Conway, Editors, p. 29, Plenum Press, New York (1990).

4. A. H. Zimmerman, in Hydrogen and Metal Hydride Batteries, P. D. Bennett and T. Sakai, Editors, PV 94-27, p. 268, The Electrochemical Society Proceedings Series, Pennington, NJ (1994).

5. N. Sac-Epée, M. R. Palacín, B. Beaudoin, A. Delahaye-Vidal, T. Jamin, Y. Chabre, and J-M. Tarascon, J. Electrochem. Soc., 144, 3896 (1997).

6. J. T. Brown and M. G. Klein, in Proceedings of the 12th Annual Battery Conference on Applications and Advances, 97TH8226, H. A. Frank and E. T. Seo, Editors, IEEE, p. 33 (1997).

7. H. Bode, K. Dehmelt, and J. Witte, Electrochim. Acta, 11, 1079 (1966).

8. D. Singh, J. Electrochem. Soc., 145, 116 (1998).

9. M. Oshitani, M. Watada, T. Tanaka, and T. Iida, in Hydrogen and Metal Hydride Batteries, P. D. Bennett and T. Sakai, Editors, PV 94-27, p. 303, The Electrochemical Society Proceedings Series, Pennington, NJ (1994)

10. D. E. Reisner, A. J. Salkind, P. R. Strutt, and T. D. Xiao, J. Power Sources, 65, 231 (1997).

11. K. Hasegawa, M. Ohnishi, M. Oshitani, K. Takesima, and Y. Matsumaru, Z. Phys. Chem., 183, 1365 (1994).

12. M. Oshitani, K. Hasegawa, and H. Yufu, U.S. Pat. 4,985,318 (1992).

13. F. Lichtenberg and K. Kleinsorgen, J. Power Sources, 62, 207 (1996).

14. R. Kostecki, T. Richardson, and F. McLarnon, J. Electrochem. Soc., 145, 2380 (1998).

15. R. D. Armstrong, G. W. D. Briggs, and E. A. Charles, J. Appl. Electrochem., 18, 215 (1988)

16. S. F. Pensabeme, U.S. Pat. 3,826,684 (1974).

17. P. Dugleux, M. Dominé-Berges, A. Boullé, Bull. Soc. Chim. Fr., 20, 1603 (1960).

18. M. V. Vázquez, M. A. Avena, and C. P. De Paul, Electrochim. Acta, 40, 907 (1995).

19. Joint Committee on Powder Diffraction Standards (JCPDS) $\beta$ - NiOOH, Card No. 6-0141.

20. J. M. MacArthur Rodriguez, J. Morales, and J. L. Tirado, J. Mater. Sci., 21, 3668 (1986).

21. K. Watanabe, T. Kikuoka, and N. Kumagai, J. Appl. Electrochem., 25, 219 (1995).

22. I Krejci and P. Vanysek, J. Power Sources, 47, 79 (1994).

23. K. S. Han and M. Yoshimura, J. Mater. Res., 13, 880 (1998). 